\title{
The end of justice(s)
}

Citation for published version (APA):

van Zelst, B. (2018). The end of justice(s): perspectives and thoughts on automation in dispute resolution. Maastricht University. https://doi.org/10.26481/spe.20180608bz

Document status and date:

Published: 08/06/2018

DOI:

$10.26481 / \mathrm{spe} .20180608 \mathrm{bz}$

Document Version:

Publisher's PDF, also known as Version of record

\section{Please check the document version of this publication:}

- A submitted manuscript is the version of the article upon submission and before peer-review. There can be important differences between the submitted version and the official published version of record.

People interested in the research are advised to contact the author for the final version of the publication, or visit the DOI to the publisher's website.

- The final author version and the galley proof are versions of the publication after peer review.

- The final published version features the final layout of the paper including the volume, issue and page numbers.

Link to publication

\footnotetext{
General rights rights.

- You may freely distribute the URL identifying the publication in the public portal. please follow below link for the End User Agreement:

www.umlib.nl/taverne-license

Take down policy

If you believe that this document breaches copyright please contact us at:

repository@maastrichtuniversity.nl

providing details and we will investigate your claim.
}

Copyright and moral rights for the publications made accessible in the public portal are retained by the authors and/or other copyright owners and it is a condition of accessing publications that users recognise and abide by the legal requirements associated with these

- Users may download and print one copy of any publication from the public portal for the purpose of private study or research.

- You may not further distribute the material or use it for any profit-making activity or commercial gain

If the publication is distributed under the terms of Article $25 \mathrm{fa}$ of the Dutch Copyright Act, indicated by the "Taverne" license above, 
Prof.dr. Bas van Zelst

Faculteit der Rechtsgeleerdheid

The end of justice(s): perspectives and thoughts on automation in dispute resolution 


\section{The End of Justice(s)?}

\section{Perspectives and thoughts on automation in dispute resolution}

Introduction

It has been submitted that the implementation of technological innovations in dispute resolution processes reduces error and improves consistency in legal decision-making. It is also considered to be cost and time efficient and to benefit access to justice. ${ }^{1}$

An issue that has received little exposure is that of the impact of automation on the rights adjudicated. In other words: does (partly) automated dispute resolution lead to the same results as procedures conducted by human actors? I will assess this question from three angles: computer science, (cognitive and social) psychology and experiences with automation in the context of US administrative law.

It is my submission that the debate on automation in adjudication should not be geared towards what's in emerging technologies. Rather, we should ask ourselves the question what we want to get out of automated adjudication. We should, I argue, focus on the question what we want computers to do when it comes to the administration of justice, and not on what they can do.

\section{The current status of technological developments in (online) dispute resolution}

When we talk or read about the application of technology in dispute resolution processes, we tend to see this as something of the future. Fact of the matter is, however, that the developments in the field have been ongoing for over twenty years, and some say over 70 years. ${ }^{2}$

A field in which technology is increasingly employed is that of online dispute resolution ("ODR"). ODR encompasses a broad range of approaches, offering the potential for facilitating hybrid processes including (a combination of) online and offline dispute resolution. ${ }^{3}$ ODR is, however, not a dispute resolution mechanism in itself. ODR systems have historically been designed as communication platforms, aimed at facilitating outcomes in alternative dispute resolution (“ADR") processes without the

\footnotetext{
${ }^{1}$ See, amongst others; R.W. Staudt, 'All the Wild Possibilities: Technology That Attacks Barriers to Access to Justice', 42 Loyola of Los Angeles Law Review 1117; James E. Cabral et al, 'Using technology to enhance access to justice', 26 Harvard Journal of Law \& Technology 243; Michael J. Wolf, 'Collaborative technology improves access to justice', 15 New York University Journal of Legislation and Public Policy 759. For a comparative discussion of ODR as an access to justice issue; Anjanette $\mathrm{H}$. Raymond \& Scott J Shackelford, 'Technology, Ethics, and Access to Justice: Should an Algorithm Be Deciding Your Case?', 35 Michigan Journal of International Law 485, at 487 et seq.

2 Yannopoulos considers Loevinger's 1949 article Jurimetrics the starting point. See: Lee Loevinger, 'Jurimetrics-The Next Step Forward', 33 Minnesota Law Review 455 and Georgios N Yannopoulos, 'Modelling the Legal Decision Process for Information Technology Applications in Law', Boston: Kluwer Law International, 1998 at 15.

For a discussion of the historical development of 'computers and law' more generally; Jon Bing, 'Computers and Law: Some Beginnings (computer Und Recht - Die Anfänge) ', 49 It - Information Technology 71.

${ }^{3}$ D. Rainey and A. Tidwell, 'Online Technology: The new Frontier for Mediation and Conflict Engagement', in: A Georgakopoulos (eds.), 'The Mediation Handbook Research, theory, and practice', Oxford: Routledge 2017. Mohamed S. Abd al-Wahhāb et al., 'Online Dispute Resolution: theory and practice: a treatise on technology and dispute resolution', The Hague: Eleven International Publishing 2012.
} 
need for physical presence at a meeting or hearing. ${ }^{4}$ It thereby provides a more cost-effective alternative to traditional approaches to dispute resolution. ${ }^{5}$

\subsection{History and features of ODR platforms}

The development of ODR platforms commenced as early as the mid-1990s. ${ }^{6}$ These efforts where at first of a more exploratory nature, focusing on testing technological solutions. The first commercial ODR applications emerged quickly, however. ${ }^{7}$ As early as 2004, an estimated 115 private ODR providers where in business. ${ }^{8}$ This number had decreased to about 40 by $2010 .{ }^{9}$ The website www.odr.info currently lists around 70 providers of online dispute resolution services. ${ }^{10}$

Most offer a service based on a web-based forum which allows users to attempt to resolve differences on their own - with the help of suggestions rendered by an online communication tool offered by the service provider. So essentially: the disputants negotiate online and the computer may provide suggestions for possible outcomes which the disputants may choose to accept. Where necessary parties may choose to escalate the dispute to a professional mediator or arbitrator. This third party may facilitate amicable discussion, suggest a solution and/or render a decision. ${ }^{11}$

A service provider often referred to in literature on ODR is Modria. Modria is an online dispute resolution tool aimed at the resolution of common, generally small, claims. It is a spin-off of eBay and PayPal's resolution centers. Since 1995, these resolution centers have processed hundreds of millions of cases, largely $(90 \%)$ through fully automated procedures not requiring human intervention.

Modria claims to be capable of handling all manner and volume of cases, from simple debt cases to complex child custody matters. The Modria platform uses a four-stage process: diagnosis, negotiation, mediation, and finally arbitration. Going through these motions, the process develops from a partycontrolled complaint process (stage 1 ) to a process managed by a third-party neutral (stage 2 ). The third stage of the process includes a third-party mediator (or decision facilitator). In case the matter is not resolved at this stage, a third-party arbitrator renders a final and binding decision. This arbitral award may - if necessary - be enforced through the courts.

\footnotetext{
${ }^{4}$ See: Karolina Mania, 'Online Dispute Resolution: The Future of Justice', 1 International Comparative Jurisprudence, 76-86 (2015) at 78; and Pavel Loutocký, 'Online Dispute Resolution to Resolve Consumer Disputes from the Perspective of European Union Law: Is the Potential of Odr Fully Used?', 10 Masaryk University Journal of Law and Technology, 113-113 (2016).

${ }^{5}$ Carole D. Hafner \& Donald H. Berman, 'The Potential of Artificial Intelligence to Help Solve the Crisis in Our Legal System', 32 Communications of the Acm (1989); Gralf-Peter Calliess, 'Online Dispute Resolution: Consumer Redress in a Global Market Place', 7 German Law Journal (2006).

${ }^{6}$ See: Abd al-Wahhāb, supra note 3; and Noam Ebner \& John Zeleznikow, 'No Sheriff in Town: Governance for Online Dispute Resolution', 32 Negotiation Journal, 297-323 (2016) at 298 et seq.

${ }^{7}$ Tyler distinguishes four phases in the development of ODR. Melissa Conley, 'Seventysix and counting: Analysis of ODR sites', in: Arno R. Lodder et al. (eds), 'Essays on legal technical aspects of Online Dispute Resolution', Papers from the ICAIL 2003 ODR Workshop (2003).

${ }^{8}$ Melissa Conley Tyler, '115 and Counting: The State of ODR 2004', in: Melissa Conley Tyler et al. (eds), Proceedings of the third annual forum on online dispute resolution. Bangkok: International Conflict Resolution Centre in Collaboration with the United Nations Economic and Social Commission for Asia and the Pacific (2005).

${ }^{9}$ M. Suquet, et al., 'Online Dispute Resolution in 2010: a Cyberspace Odyssey?', in: M. Poblet, B. Abrahams \& J. Zeleznikow, 'Proceedings of the 6th international workshop on online dispute resolution', pp.1-12.

${ }^{10}$ http://odr.info/provider-list/.

${ }^{11}$ See for a discussion of a variety of decision support systems in dispute resolution: Arno R. Lodder \& John Zeleznikow, 'Enhanced Dispute Resolution through the Use of Information Technology', Cambridge: CUP 2010, at 86 et seq.
} 
Some private ODR platforms provide their own enforcement tools. A party not willing to comply with the outcome of the dispute resolution process may see its account suspended. Other enforcement tools include other users being allowed to post negative feedback, delay of payment, or the application of charges. ${ }^{12}$ These means of compliance - payment mechanisms in particular - are often heralded as essential features of successful private ODR platforms. ${ }^{13}$

\section{$2.2 \quad$ Future developments}

Although it has been submitted that it is unlikely that human oversight can be fully removed from legal decision-making systems, ${ }^{14}$ recent developments suggest a potential shift towards further application of algorithmic assistance in (online) decision-making. ${ }^{15}$ There is an increasing number of platforms that provide dispute resolution services that do not require the involvement of a human actor. ${ }^{16}$ These developments represent a fundamental shift from ODR as a web-based communications tool, to an intelligent system, an algorithm designed to assist settlements by suggesting outcomes or even make decisions itself. ${ }^{17}$

Furthering technology is at the same time considered a "necessary evil"18 and "vital"19 to the survival of ODR platforms. A necessary evil, as technological development increases the access to justice potential of the ODR environment and may help mitigate potential hindrance due to the uncertainty created by the newness of the system and the lack of enforcement mechanisms. ${ }^{20}$ On the other hand, technological development is vital as a cost-reduction strategy. The costs associated with the maintenance, upkeep, and service of ODR platforms are widely considered a threat to their long-term survival. ${ }^{21}$ Strong evidence for this position can be derived from the large turnaround in the number of available platforms and is congruent with the difficulty of passing on costs to users in view of the large number of low-value disputes resolved through such platforms.

The challenges faced by ODR platforms provide valuable insights for the development (and utilization) of automated dispute resolution mechanisms by public courts. Swelling court dockets, shrinking budgets and rising concerns about access to justice provide incentives for governments to investigate the potential of automation in the public domain. In view of the importance of state courts at least as providers of residual access to justice, let us consider three perspectives that could play a part in the analysis of the feasibility and desirability of state administrated automated dispute resolution.

\footnotetext{
12 Raymond and Shackleford, supra note 1 , at 502 et seq.

${ }^{13}$ Vikki Rogers, 'Knitting the Security Blanket For New Market Opportunities', in: Abd al-Wahhāb et al (eds), supra note 3, at 115.

14 Jay Thornton, 'Cost, Accuracy, and Subjective Fairness in Legal Information Technology: A Response to Technological Due Process Critics', 91 New York University Law Review 1821, at 1846.

${ }^{15}$ Dusty Bates Farned, 'A New Automated Class of Online Dispute Resolution: Changing the Meaning of Computer-Mediated Communication', 2 Faulkner L. Rev. 335, at 343.

${ }^{16}$ Including the dispute resolution mechanisms employed on the Amazon and Uber platforms.

${ }^{17}$ Beth Trent \& Colin Rule, 'Moving Arbitration Online: The Next Frontier', N.Y. L.J., Apr. 1, 2013, at S6.A.

${ }^{18}$ Scott J. Shackelford and Ajanette H. Raymond, 'Building the Virtual Courthouse: Ethical Considerations for Design, Implementation, and Regulation in the World of Odr,' 2014 Wisconsin Law Review 615 at 628.

${ }^{19}$ Raymond and Shackleford, supra note 1 at 521.

${ }^{20}$ Shackleford and Raymond, supra note 18 at 628.

${ }^{21}$ Ibid.
} 
The first of these perspectives is that of computer science. From the academic debate in this field, I draw three challenges to automation in dispute resolution. They are of a jurisprudential (Section 3.1), technical (Section 3.2) and political (Section 3.3) nature respectively.

\subsection{Jurisprudential challenges}

The systems that are envisaged to play a part in the administration of justice - so-called legal expert systems - are based on the (oversimplified) idea that one can have a group of experts extract applicable rules from a body of law, translate these rules into a formalism that a computer is capable of processing, and a decision will come out the other end. ${ }^{22}$ The positivist notion of law as a formal rule-governed process that allows for the mechanical application of a mere set of rules has, however, been challenged on fundamental grounds.

Dworkin has submitted that legal reasoning is not a deductive, rule-based exercise, as proponents of legal positivism argue. ${ }^{23} \mathrm{He}$ argues that the law consists not only of rules but also of principles. ${ }^{24}$ Rules are applicable in an all-or-nothing fashion, whereas principles have the extra dimension of relative weight, making them "not, even in theory, subject to enumeration". ${ }^{25}$ Proponents of automation of the law have sought to address this critique by pointing to the fact that Dworkin's position does not challenge the legal positivist notion that - at least in clear cases - legal questions may be decided by the application of rules. They submit that Dworkin's argument does not prejudice the development of only rule-based expert systems, ${ }^{26}$ nor would Dworkin's position interfere with data-centric automated adjudication. After all, Dworkin does not challenge that the law does provide a 'right answer' to each question of law.

The law being, at least to some extent, determinate and capable of generating a right answer is not a universally accepted notion. It has been challenged by the legal realist movement of the early 1920s. Rejecting the then dominant mode of formalism, the legal realists argued that legal rules cannot guide courts to definite results in particular cases. ${ }^{27}$ The Critical Legal Studies movement and the New Legal

22

Philip Leith, 'The Rise and Fall of the Legal Expert System†', 30 International Review of Law, Computers \& Technology, 94106 (2016) at 97.

${ }^{23}$ A telling anecdote is the story of a conversation between eminent US judges Oliver W. Holmes and Learned Hand: "Learned Hand was visiting Washington and went to lunch with Justice Holmes. They walked back to the Capitol. The Court was still sitting there in the Old Senate Chamber. As they parted, Hand called, "Sir, do justice." The old man turned on him fiercely, eyebrows bristling: "Justice? What's that? That's none of my business. Law is my business." See: Abram Chayes, 'How Does the Constitution Establish Justice?', 101 Harv. L. Rev. 1026, 1041 (1988). Even though accounts of this horse-and-buggy age tale differ, all variations strikingly expresses the "age-old struggle" to define the relation between law and justice. See: Michael Herz, 'Do Justice!": Variations of a Thrice-Told Tale', 82 Virginia Law Review 111, at 112.

24 Susskind summarizes Dworkin's position as claiming inter alia that: "(1) there is more to legal reasoning than deduction from rules; and (2) any attempt to formalize the contents of a legal system is misconceived." Richard E Susskind, 'Expert Systems in Law: A Jurisprudential Inquiry', Oxford: Clarendon 1987

, at 171-172.

${ }^{25}$ Ronald Dworkin, 'Taking Rights Seriously', London: Duckworth 1978

, at 25.

${ }^{26}$ Susskind, supra note 24 at 174 .

${ }^{27}$ On the relation between formalism and realism: Brian Leiter, 'Legal Formalism and Legal Realism: What Is the Issue?', 16 Legal Theory 111. 
Realists ${ }^{28}$ have further developed this argument of the lack of determinative meta-principles in law. This lack of determinability poses a serious jurisprudential challenge to automation in dispute resolution. After all, if it is not clear what is 'the law', how can a computer be asked to apply it? ${ }^{29}$

\subsection{Technical challenges}

Apart from the question whether legal expert systems can theoretically provide right answers to legal questions, automated decision-making faces technical challenges. For rule-based systems these challenges lie in the impossibility of incorporating all relevant considerations in deciding a case into the system. This is problematic as, in the words of Bench, "the expertise that a good lawyer has is less a matter of knowledge, whether knowledge that or knowledge how, but rather certain habits of thought, particular ways of approaching a problem, and recognising the ways in which information needs to be used." 30

Data-centric approaches may be capable of working around this problem as they do not require laborious human encoding of legal texts in logical formalisms. However, these benefits come at a cost. Assuming that it can be established what factors in our complex legal system are relevant to the outcome of a case, the large number of such factors being relevant to a particular case lead to decreased transparency and explanatory capability and make it impossible for human actors to comprehend (and probe) the outcome proposed or defined by the model. As such, data-centric systems are 'black-boxes' that are subject to misuse. ${ }^{31}$

Lastly, a technical aspect that is often overlooked is that of changing social norms. Our views on what is to be considered reasonable, appropriate or even lawful change overtime. This brings the question to what extent computer systems are capable of incorporating changing social norms.

\subsection{Political challenges}

A last challenge relevant to the inquiry at issue is of a more political nature. Most writings on computerization of legal processes focus on technical and economic issues. This focus on 'technicalities' is incongruent to the recognition of the issue of 'automation bias'.

Basically, automation bias is the fact that "behind software programmes are individuals, with values and preferences, and whose choices are grounded in their own worldview and reflect societal power structures and individual biases". ${ }^{2}$ To put this in an example: when you are driving - or better: when you sit back in your - self driving Tesla and an accident happens, the car will decide to either run into the tree or into the old lady. Whatever the decision the car makes, there is someone that has

\footnotetext{
${ }^{28}$ For a discussion of the relation between the Legal Realists and Critical Legal studies: Bastiaan van Zelst, 'The Politics of European Sales Law: A Legal-Political Inquiry into the Drafting of the Uniform Commercial Code, the Vienna Sales Convention, the Dutch Civil Code and the European Consumer Sales Directive in the Context of the Europeanization of Contract Law', Alphen aan den Rijn: Kluwer Law International 2008, at 16 et seq. For a discussion of the development of the (new) realist movement: T.J Miles \& C.R Sunstein, 'The New Legal Realism', 75 University of Chicago Law Review 831.

${ }^{29}$ V. R Benjamins et al., 'luriservice: An Intelligent Frequently Asked Questions System to Assist Newly Appointed Judges', 3369 Lecture Notes in Computer Science 201.;Leith, supra note 22, at 100.

${ }^{30}$ T. Bench-Capon, 'What makes a System a Legal Expert?', in: B. Schäfer, 'Legal Knowledge and Information Systems', Amsterdam: IOS Press 2012, at 18, noting that future developments may provide an answer to these challenges. 31

L. Karl Branting, 'Data-Centric and Logic-Based Models for Automated Legal Problem Solving', 25 Artificial Intelligence and Law 5 , at 19 .

${ }^{32}$ Orna Rabinovich-Einy \& Ethan Katsh, 'Digital Justice: Reshaping Boundaries in an Online Dispute Resolution Environment', 1 International Journal of Online Dispute Resolution 5, at 36.
} 
programmed the car to act the way it does. And that engineer has a certain view of the world, which view may be reflected in the algorithm.

Automation bias gives rise to concerns as to whether the algorithms employed in dispute resolution are and will in the future adequately reflect substantive laws adjudicated through such systems. These concerns arise at hypothetically two levels. First, the developments discussed in the above suggest that in the (maybe not so distant) future computer systems will prove able to adjudicate questions of law with relative certainty. ${ }^{33}$ Those involved in the development of such systems may be inclined ${ }^{34}$ to build the system in such a way that the systems make decisions coinciding with his/her values, making that person a 'judge by proxy'. This quite clearly is in contravention of the democratic constitutional tradition, which requires transparency both with respect to who applies the law and how it is applied. It might, however, also be that deep learning is developed in such a way that it may adjudicate cases and develop its 'view' of the law on a stand-alone basis. Here, the developer of the system cannot be called upon to explain how his/her machine is capable of resolving matters the way it does. Although this may be a rather farfetched prospect, it does invite more current questions relating to what is the level of transparency required in computer systems and how this transparency should be communicated. In other words: should judges be schooled to write software? Should the software developer be called upon to explain the working of the system?

Perspectives from the social sciences

The second perspective I would like to draw your attention to is that of the social sciences. Viewed from this perspective, it is surprising that the interaction between humans and technological innovations in law has received only limited attention. This is all the more true given the fact that in most predictions automation will not supplant human activity but will rather change the nature of the work done under human supervision. ${ }^{35}$ To put it differently: just as machines only help people to build cars and do not build cars themselves, computers are more likely to assist human decision-making than to totally replace it.

This human factor has attracted more attention in other academic disciplines. In the field of pharmacology, for instance, research has been conducted on the influence of new technologies on errors in the prescribing process. ${ }^{36}$ And in aviation psychology it has been assessed whether additional human oversight can help mitigate the risks associated with the use of automation. ${ }^{37}$ Lastly, also in the (more legalistic, if I may) fields of risk and compliance ${ }^{38}$ and credit scoring, ${ }^{39}$ the influence of the application of technology has been scrutinized.

In (civil law) dispute resolution, to the contrary, the interrelation between the combined involvement of humans and automation has remained underexposed. Against this background, I care to discuss

\footnotetext{
${ }^{33}$ Let us leave aside for now the question what level of certainty would be required to actually employ such system, having setoff the disadvantages of automated decision-making against the perceived advantages.

${ }^{34}$ It is irrelevant whether this would be for pecuniary or ideological reasons (which may be the same thing altogether).

${ }^{35}$ Pasuraman 1997, infra note 40, notes "often in ways unintended and unanticipated by the designers of automation."

${ }^{36}$ Manuel Vélez-Díaz-Pallarés et al., 'Technology-Induced Errors Associated with Computerized Provider Order Entry Software for Older Patients', 39 International Journal of Clinical Pharmacy 729.

${ }^{37}$ L.J. Skitka et al., 'Automation Bias and Errors: Are Crews Better Than Individuals?', 10 The International Journal of Aviation Psychology 85.
}

\footnotetext{
${ }^{38}$ Kenneth A. Bamberger, 'Technologies of Compliance: Risk and Regulation in a Digital Age', 88 Tex. L. Rev. 669, at 740.

${ }^{39}$ Danielle K. Citron and Frank Pasquale, 'The Scored Society: Due Process for Automated Predictions', 89 Washington Law Review 1.
} 
research from the field of cognitive psychology focusing on the interaction between automated systems and human actors (human-system interaction), as well as the acceptability of computerized dispute resolution from the perspective of social psychology.

\subsection{The human factor in automation}

In a 1997 article, Pasuraman and Riley reviewed 120 papers related to human interaction with automation in the fields of aviation, manufacturing, ground transportation, and medicine. ${ }^{40}$ Pasuraman and Riley characterize mismatches between inappropriate expectations and requirements regarding the support operators. These mismatches are categorized in terms of use, misuse, disuse, and abuse of automation.

Pasuraman and Riley note that the motivation for use of automation may differ. A fundamental reason for introducing automation is the reduction of human workload and reducing the risk of error. They find that automation - contrary to what one might expect - often does not have the effect of reducing workload. This may be explained by high-level automated systems often being engaged in probabilistic environments. This leads the human operator to spend considerable time in (put simply) 'checking' the results of the system. This may lead the human operator to perform the task manually as the advantage of automation is perceived insufficient to overcome this 'cognitive overhead'. ${ }^{41}$

Misuse of automation refers to the various aspects in which operators rely on poorly operating automation. This overreliance can result from various forms of human error, such as monitoring failures (the operator not recognizing automation breakdowns), decision bias (which may foster the tendency to "disregard or not search for contradictory information in light of a computer-generated solution that is accepted as correct"42), and complacency (insufficient monitoring and checking of automated functions).$^{43}$ Although effects may be mitigated by means of training practices, ${ }^{44}$ also skilled operators may show misplaced faith in the accuracy of the outcome of the automation. ${ }^{45}$

Disuse concerns situations where automation is not employed although it could enhance performance. Disuse may appear in situations where automation is perceived as threatening to the status quo, lack of functionality in automation or lack of developed trust in the automation's capability. Moreover, 'false alarms' - warnings that are perceived to be given by the system too frequently - may also have a deterring effect on the use of automation.

Abuse, lastly, is described as "the automation of functions by designers and implementation by managers without due regard for the consequences for human (and hence system) performance and

\footnotetext{
${ }^{40}$ Raja Parasuraman and Victor Riley, 'Humans and Automation: Use, Misuse, Disuse, Abuse', 39 Human Factors: The Journal of the Human Factors and Ergonomics Society 230.

${ }^{41}$ However, "automation use decisions are based on a complex interaction of many factors and are subject to strongly divergent individual considerations", including factors such as "automation reliability, trust in the automation, self-confidence in one's own capabilities, task complexity, risk, learning about automation States, and fatigue." Parasuraman and Riley, supra note 40 at 238. ${ }^{42}$ Mary L Cummings, 'Automation and Accountability in Decision Support System Interface Design', 32 The Journal of Technology Studies 1.

${ }^{43}$ Raja Parasuraman \& Dietrich Manzey, 'Complacency and Bias in Human Use of Automation: An Attentional Integration', 52 Human Factors 381.

${ }^{44} \mathrm{~J}$. Elin Bahner et al., 'Misuse of Automated Decision Aids: Complacency, Automation Bias and the Impact of Training Experience', 66 International Journal of Human - Computer Studies 688.

${ }^{45}$ Richard P. Will, 'True and False Dependence on Technology: Evaluation with an Expert System', 7 Computers in Human Behavior 171.
} 
the operator's authority over the system". ${ }^{46}$ Pasuraman and Riley note that abuse may be a consequence of focus on technical and economic factors in automation, without sufficient attention to human performance in the resulting system. This seems, if I may anticipate on my conclusion, a particular concern in the context of automated adjudication.

In sum, findings from cognitive psychology suggest that the introduction of automation in adjudicative processes may bring challenges to the effective application of the law in individual cases. I do note that that bias may work both ways. A human adjudicator may be prone to (unintentionally) favour tall over short, male over female and/or white over black disputants. ${ }^{47}$ That does not take away from the relevance of these findings in the context of automation in dispute resolution processes.

\subsection{The relevance of procedural fairness}

Proponents of automation in (online) dispute resolution have focused on what is presented as objective benefits to such automation (cost savings, access to justice). In the field of social psychology/sociology a vast literature has developed on how legal systems are perceived subjectively. This literature focuses on the factors that determine a user's perception of the fairness of the procedure applied to reach an outcome, rather than the outcome itself. This differentiation between form and substance has its roots in the Aristotelian distinction between distributive and corrective justice. Distributive justice concerns the division of shares in social benefits and burdens; corrective justice involves the rectification of injustice. ${ }^{48}$ Against this background 'procedural justice' may be understood as the means by which social groups (including governments, private institutions, and families) apply the requirements of corrective and distributive justice to particular cases. ${ }^{49}$

The research on perceptions of legal fairness has thus focused on a specific aspect of the concept: procedural fairness. Although the dichotomy between substance and procedure is highly debated, ${ }^{50}$ this research is nevertheless relevant for current purposes as it asks how dispute resolution mechanisms are perceived by disputants. In other words: what makes people accept a decision?

Leventhal has proposed that in an individual's perception of fairness six 'fairness factors' play a part: consistency, bias suppression, accuracy of information, correctability, representativeness and ethicality. ${ }^{51}$ Tyler has suggested an alternative framework in which the primary factors determinative of legal fairness are (i) the possibility for a disputant to participate in the process, (ii) the honesty, impartiality and objectivity of the authorities involved, (iii) trust in the third-party authority responsible for resolving the case, and (iv) the degree to which the disputants are treated respectfully. ${ }^{52}$

\footnotetext{
${ }^{46}$ Parasuraman and Riley, supra note 40, at 246.

${ }^{47}$ Kimberly Papillon, 'The Court's Brain: Neuroscience and Judicial Decision-making in Criminal Sentencing', 49 CT. REV. 48, at 49.

${ }^{48}$ Aristotle, 'Ethica Nicomachea', in: W.D. Ross (eds), 'The works of Aristotle translated into English', Oxford: OUP 1915.

${ }^{49}$ Lawrence B. Solum, 'Procedural Justice', 78 S. Cal. L. Rev. 181, at 238.

${ }^{50}$ Duncan Kennedy, 'Form and Substance in Private Law Adjudication', 89 Harvard Law Review 1685. See for a more recent discussion: Philip Soper, 'On the Relation between Form and Substance in Law', 20 Ratio Juris 56.
}

${ }^{51}$ Gerald S. Leventhal, 'What Should Be Done with Equity Theory? New Approaches to the Study of Fairness In Social Relationships', in: Kenneth J Gergen et al., 'Social Exchange : Advances in Theory and Research', New York: Plenum Press 1980. See also: E.A. Lind et al., 'The Social Psychology of Procedural Justice', Boston: Springer US 1988, discussing the history of procedural justice research at length.

52 Tom R. Tyler, 'Social Justice: Outcome and Procedure', 35 INT'L J. PSYCHOL. 117, at 121-22. 
Thornton submits that automated legal decision-making ranks favourably on a number (but not all) of these parameters for subjective perceptions of legal fairness. ${ }^{53} \mathrm{He}$ points to recent technological developments entailing that legal decision systems are not "necessarily more restrictive of participant expression than their manual counterparts" (Leventhal's representativity factor and Tyler's presentation and respectful treatment factors). Moreover, Thornton submits, a well-documented driver not considered in the frameworks proposed by Leventhal and Tyler is that of promptness and lack of delay in legal processes. In short, disputants tend to perceive a system that resolves matters more swiftly to also be more fair. ${ }^{54}$

Experiences in (US) administrative law

Lastly, I would like to share with you some ideas on 'computerized law in action'. In this respect, the developments in administrative law in the United States provide useful insights. In fact, most of us here have dealt with it when requesting an electronic travel authorization ("ESTA") for travelling to the United States. Such a request is processed without human intervention with the use of algorithms and what is referred to as 'Big Data'. As in other US administrative law systems, it is the computer that has become the "primary decision maker". ${ }^{55}$

It has been submitted that this process of automation has generated unforeseen problems for the adjudication of individual rights. This has prompted the question whether existing procedural legal structures are capable of managing the automation process. ${ }^{56}$ In this context it has been noted that "the opacity of automated systems prevents an easy determination of the source of the error." 57 This gives rise to concerns with respect to effective (judicial) review for three reasons. First, the recipients of decisions generated by the systems are not capable of assessing the odds of succeeding in (court) proceedings. This may deter them from seeking recourse to a higher authority. Secondly, should an individual nevertheless choose to commence proceedings, opacity of the reasons underlying the disputed outcome pose the problem for the adjudicator (on appeal) to assess the source of the (allegedly) incorrect outcome. Thirdly, should the adjudicator come to a decision that is contrary to the outcome generated by the decision, difficulties are likely to arise in amending the erroneous parts of the code, causing concerns as to continued incorrect application of the law in other cases.

\section{Conclusion}

The foregoing assessment gives rise to concerns with respect to the compatibility of automated decisionmaking with existing substantive norms, market pressures incentivizing unbalanced algorithms (automation bias) and perils of human interaction with automation (decision bias, complacency and monitoring failures) more generally. These concerns are exacerbated by a lack of (judicial and regulatory) supervision of automated decision-making systems. As a consequence, there is a large likelihood that results generated by or with the help of automation are to differ from the outcomes produced by our current adjudicative mechanisms.

I therefore disagree with the assessment that, "on the face of it, there are no knockdown objections, no overriding concerns of law or principle, that should call a halt to the ongoing and advanced

\footnotetext{
${ }^{53}$ Thornton, supra note 14 at 1849.

${ }^{54}$ Ibid.

${ }^{55}$ Danielle K Citron, 'Technological Due Process, 85 Washington University Law Review', 1249, referring to Denise Kersten,

'Bytes vs. Brains', GOV'T EXEC., Sept. 1, 2005, at 30.

${ }^{56}$ This scholarship is referred to as 'Technological due process'.

${ }^{57}$ Citron, supra note 55 at 1279.
} 
computerization of courts." ${ }^{8}$ It seems to me the debate on what constitutes an overriding concern of principle (or even law, for that matter) is in its infancy and any conclusions on this issue are premature. Although we are getting more and more familiar with its (increasing) benefits, we have not even begun to fathom the societal impact the automation of dispute resolution mechanisms may have, nor do we understand what is the impact of automation in dispute resolution on acceptance of computer generated 'judicial' decisions', the efficacy of appeal proceedings and the availability of (human) judges. The findings I presented suggest that a further assessment of these (and other) issues, is vital to a reasoned discussion of the pros and cons of automation in law.

It is these assessments that I envisage to contribute to in both my capacities. It is, after all, in furthering society through (reasoned) debate where the roles of the academic and the practicing attorney converge.

Ik heb gezegd

${ }^{58}$ Richard E Susskind, 'Tomorrow's Lawyers: An Introduction to Your Future', Oxford OUP 2013, at 68. 